\title{
In Response: The Ideal Psychiatry Residency Training Program
}

\author{
Allan Tasman, MD \\ University of Connecticut Health Center, Farmington Connecticut
}

Follow this and additional works at: https://jdc.jefferson.edu/jeffjpsychiatry

Part of the Psychiatry Commons

Let us know how access to this document benefits you

\section{Recommended Citation}

Tasman, MD, Allan (1988) "In Response: The Ideal Psychiatry Residency Training Program," Jefferson Journal of Psychiatry. Vol. 6 : Iss. 2 , Article 12.

DOI: https://doi.org/10.29046/JJP.006.2.012

Available at: https://jdc.jefferson.edu/jeffjpsychiatry/vol6/iss2/12

This Article is brought to you for free and open access by the Jefferson Digital Commons. The Jefferson Digital Commons is a service of Thomas Jefferson University's Center for Teaching and Learning (CTL). The Commons is a showcase for Jefferson books and journals, peer-reviewed scholarly publications, unique historical collections from the University archives, and teaching tools. The Jefferson Digital Commons allows researchers and interested readers anywhere in the world to learn about and keep up to date with Jefferson scholarship. This article has been accepted for inclusion in Jefferson Journal of Psychiatry by an authorized administrator of the Jefferson Digital Commons. For more information, please contact: JeffersonDigitalCommons@jefferson.edu. 


\title{
In Response
}

\section{The Ideal Psychiatry Residency Training Program}

\author{
Allan Tasman, M.D.
}

There is little to be added in the way of specifics to James Deming's review of the necessary ingredients for an ideal Residency Training Program (1). He not only reviews the specific issues which must be addressed regarding the "nuts and bolts" of training, but also emphasizes the need for phase specificity of both clinical and didactic experiences and the need to view residency training from a developmental perspective. Rather than comment specifically on the points Deming raises, I would like to address other ingredients in residency training which are to be valued in the ideal program.

With the explosion of knowledge in the field over the last several decades, training directors and faculty, as well as trainees, are faced with enormous concerns about how this information can be most usefully presented and integrated. My own bias places this task under the rubric of needing to learn an appreciation for process. This phenomenon is often discussed primarily from the perspective of psychotherapy practice, but I mean something different here. The biopsychosocial model encompasses a view that in understanding the individual, we must be prepared to understand the processes within that person from biologic, intrapsychic, interpersonal, familial, and environmental points of view. The ideal training program should not only provide a set of clinical and didactic experiences which cover this knowledge, but also provide a means within which these varying levels of observation and understanding of a patient can be integrated. I find that this integration occurs most effectively in the supervisors office, when a resident presents case material and is helped to put together what is seen clinically, what is experienced by the physician, and what is known about psychopathology from a variety of points of view. It is therefore essential, in order for this process to occur optimally, that the supervisors have the requisite appreciation for process and capacity to integrate different levels of understanding. Departments of Psychiatry rarely feature a monolithic approach to understanding psychopathology, although there are exceptions. It is important in the choice of those individuals who are selected for supervision, that attention be paid to the particular interests and teaching skills of faculty members. It is essential to have supervisors who not only have a specific area of expertise in psychiatric knowledge and practice, but also the capacity to 
synthesize and integrate understanding from a variety of perspectives. It is through interactions with such supervisors that we can provide the best modeling of the kind of clinical decision making and understanding which is being addressed here. Some would argue that in smaller departments, where resources are scarce, such specialization of teaching activities cannot be done. I would respond only that I am talking about an ideal situation without trying to address myself to the many clear constraints of the real world.

Another area which is an essential part of the ideal training program is the need to instill, as part of one's professional identity, a commitment to learning and the capacity to integrate new information. One might argue that the very nature of residency programs promote this because of the overwhelming body of facts, skills, and clinical capacities that must be integrated by the resident. I am talking about something a bit less concrete here, which has to do with a life long commitment to learning and a capacity to continue to integrate new information once training is completed. There is a joke commonly told around medical centers that if someone has a severe medical problem, the person that one would want to see is not the Chairman of the department, but the Chief Resident in Internal Medicine. This reflects an all too common view that once training is completed there is a sense that learning stops. No one has the perfect solution to this dilemma. I believe, however, that it is through the interaction between the resident and faculty members that this character trait can be developed, reinforced and internalized.

It is, therefore, incumbent upon Departments of Psychiatry to create an atmosphere within which the faculty members are engaged in scholarly work. This need not be basic science or wet lab research, but can be scholarly pursuits in any area of psychiatry. The identification with faculty, and incorporation of desired traits into one's own professional identity which needs to occur, requires that a commitment to learning be not only demonstrated by the number of hours of didactics which are scheduled per week, but in the approach of the faculty and residents to their own professional lives. Clearly, this requires a strong commitment from the Department Chairman.

The development of the capacity for self reflection and personal growth should also be an essential feature of the ideal program. This is often learned primarily in the context of psychotherapy training, but also needs to permeate all other parts of the curriculum. We must encourage, within a supportive and tolerant atmosphere, the personal exploration necessary for growth of these capacities.

As I hope will be apparent, the aspect of an ideal residency program that I am emphasizing here is that which encompasses a strong sense of collaborative relationship between residents and faculty. Without such an atmosphere, I believe the processes that I have outlined above do not occur very well. It is also clear to me that the creation of such an atmosphere must come from both faculty and residents. As a training director I often spend much of my time recruiting faculty for participation in a variety of educational experiences, and am aware 
that there is often inadequate time to discuss the issues that I have outlined here. Further, I believe that the pressures of residency training often make it difficult for residents to regularly address these issues. Clearly, the atmosphere within the group of residents has an impact on the faculty. There is a reciprocal relationship involved, and without both partners having the same commitment, the processes outlined here are often inhibited before they can really get going.

I believe that it is necessary that Departments of Psychiatry provide opportunities for discussion of these issues. I have found that regular opportunities for educational retreats are a very effective way to accomplish this. These retreats provide an opportunity for faculty and residents to meet together outside of the atmosphere of the day to day work world, which facilitates exploration of these important concerns. Many departments of psychiatry have found other ways to accomplish this goal. The key is not so much the specific ways that this atmosphere is created, but the need to pay continual attention to it so that the process can be fostered.

Residency programs have two tasks: training and education. Unfortunately we focus too often on those training tasks related to the "nuts and bolts" of clinical practice and the dissemination of the body of knowledge that we feel is necessary for a solid education. The ideal training program should pay equal attention to those aspects of training and education related to the development of professional identity and personal growth which happens best within an atmosphere of collegial collaboration between faculty and residents.

\section{REFERENCE}

1. Deming J: The ideal psychiatry training program: A resident's viewpoint. Jeff J Psych $5(2): 48-69,1987$ 